\title{
THE INTERPLAY OF \\ SYNTACTIC AND LEXICAL SALIENCE AND ITS EFFECT ON DEFAULT FIGURATIVE RESPONSES
}

\begin{abstract}
The aim of the paper is to determine how salient and non-salient figurative discourse nouns affect readers' default response processing and oculographic (eye-movement) reactions. Whereas the theories of the Graded Salience and the Defaultness Hypotheses, developed by R. Giora (Giora, 1999, 2003; Giora, Givoni, \& Fein, 2015), have stimulated further research in the area of interpretive salience (Giora et al., 2015; Giora, Jaffe, Becker \& Fein, 2018), the resonating influence of syntactic salience on default interpretations has been largely neglected. In this study we provide corpus-based evidence followed by eye-tracking experiment verification, supportive of the synchronized influence of syntactic and lexical salience. The results show that default figurative responses in lexically salient positions may require more cognitive effort (longer fixations) if they are syntactically less salient. Literal responses to figurative nouns may also result from either weak lexical or syntactic salience of nouns. Therefore, apart from exemplifying resonance with lexical salience (in terms of lexical frequency, familiarity, conventionality, and prototypicality), the default figurative interpretations are also syntactically dependent.
\end{abstract}

Keywords: figurative nouns, the Defaultness Hypothesis, syntactic salience, corpus-based analysis, eye-tracking experiment.

\section{Introduction}

The question of likely and unlikely interpretation routes a reader chooses when identifying the reference of figurative discourse nouns has received much attention in the research of the three recent decades. It has been unanimously agreed that this process is guided by a wide range of construal mechanisms, with the mechanism of salience being one of the most significant (Givón, 1987; Tomlin, 1987; Chafe, 1994; Giora, 1999, 2003; Talmy, 2000; Wårwik, 2004; Verhagen, 2007; Schmid, 2007; Iriskhanova, 2014). There exist two general approaches to exploring these mechanisms: one is corpus- 
based and corpus-driven (Semino \& Short, 2004; Gries \& Stefanowitsch, 2006; Golubkova, 2014; Divjak, 2015, among others); the other is experimentally rooted (Glucksberg et al., 1982; Pynte et al., 1996; Coulson \& van Petten, 2002; Kazmerski et al., 2003; Iakimova et al., 2010; Rapp et al., 2017, among others).

Recent research into the development of the Defaultness Hypothesis (e.g., Giora, Givoni, \& Fein, 2015), which postulates that constructional effects prompt default, automatic (though non-literal) interpretations, employs both corpus-based and experimental methodology. This approach makes it possible to predict and reveal the coordination of salience and default effects in language and in speech production as shown by experiment participants' interpretations. Surprisingly, very little attention in exploring lexical salience is given to the role that syntactically salient and non-salient positions play in stimulating default and non-default responses. To assess this role, we apply a complex tripartite analysis: identifying the syntactic salience parameters, evaluating their frequency in the corpus when they accompany figurative discourse nouns, and verifying them in an oculographic experiment. We hypothesize that default and non-default interpretations are resonant not only with the lexical salience of figurative discourse nouns, but also with syntactic salience, i.e. with more or less syntactically frequent positions of figurative nouns.

\section{Tripartite research methodology in figurative responses processing analysis}

To this date there exist several partly mutually exclusive hypotheses on how we process implicit information and access the figurative meaning of words in discourse. They are the direct (parallel) process model, which assumes a single mechanism for both literal and figurative meanings, the "direct meaning comes first" model, and the graded salience model, according to which coded meanings of higher salience lexemes are accessed faster (Giora, 1999). Salience here is dependent on a range of parameters including lexeme frequency in the mental lexicon, familiarity with lexeme meanings, conventionality and prototypicality of the meanings (Giora, 2003).

These hypotheses are constantly challenged in experimental and clinical research of developmental disorders (Norbury, 2005; Gold \& Faust, 2010; Vulchanova et al., 2015). The basic claim here is that the competence in figurative language comprehension relies on inferencing skills and the ability to integrate information from various sources (Gibbs, 1992; MacKey \& Shaw, 
2006; Rundblad \& Annaz, 2010). Other factors and mechanisms might also play a role in figurative language processing, such as the type of embodiment pattern activated (Barsalou, 2008; Bergen, 2012); the state of mind and inner states or mood (Charteris-Black, 2012; Kauschke et al., 2018), and probability and heuristic factors (Tversky \& Kahneman, 1974; Ritchie, 2013; Hetmański, 2015). Holistic assessment of these factors is still a challenge, although it is obvious that the interplay of various factors and mechanisms can shed light on the process of inferencing. In this study we will try to see how syntactic and lexical salience are synchronized to stimulate default and non-default responses elicitation. To select the syntactic parameters for the salience verification procedure, we will use several parameters of syntactic focusing (for example, the predicate position of a figurative noun or its position in the mononuclear sentence).

For example, in (1), the figurative noun agony (meaning 'causing agony') is in the nuclear predicate position, which is syntactically focal (figurative nouns must get into the focal position to be recognized); whereas in (2), the figurative noun phrase the little brown ball of paper (meaning 'face') occupies the subject position and is definitely less focal, while at the same time, it is lexically complex, including two modifiers (little and brown), which enhances lexical focusing:

(1) Waste even of other people's money was agony to Mr Frisby (P.G. Wodehouse).

(2) The little brown ball of paper became smaller and more screwed up (R. Dahl).

Although these parameters are clearly parameters of focusing, they still may or may not be the parameters of salience, as salience will have to be revealed through corpus frequency (with these parameters of focusing used with non-entrenched figurative nouns) and verified experimentally.

This study is aimed at revealing how syntactically focal parameters contribute to syntactic salience of novel (unconventional, non-entrenched) figurative nouns and noun phrases, and how lexical and syntactic salience parameters interact in the interpretation process of novel figurative lexemes. The first part of the study explores the syntactic parameters of salience which might influence default and non-default responses, whereas the second part experimentally discloses their role in the interpretation of figurative nouns and noun phrases. The experiment is conducted on native speakers of Russian (a typical population group, all students aged 19-22) reading a Russian prose text containing figurative language. We will show that novel 
figurative nouns and noun phrases can be processed differently (exemplifying default and non-default figurative and literal responses), depending on factors of graded syntactic salience.

In the present study, we apply a tripartite methodology by eliciting syntactic salience parameters (using the lists of parameters of focusing), testing their corpus values, and verifying their salience and synchronization specifics through running an eye-tracking experiment.

First, we explore various parameters of focusing which may serve to demarcate the borderline between literal and figurative discourse nouns and hypothesize syntactic salience parameters that resonate with novel figurative lexemes.

Next, we conduct a statistically verified corpus analysis to detect the frequency effects of the synchronization of lexical and syntactic salience parameters and search for the statistical values of several syntactic salience parameters used in literal and figurative naming. With these values we can claim prototypicality effects of some synchronization patterns.

Then, the oculographic (eye-tracking) analysis is carried out to experimentally verify the significance of these synchronization patterns and their role in eliciting default and non-default responses, i.e. in recognizing the figurative use of the discourse lexemes.

\section{Salience and default figurative responses processing}

The cognitive parameters differentiating literal and figurative discourse nouns have been vastly explored (e.g. Glucksberg \& Keysar, 1990; Giora \& Fein, 1999; Gentner et al., 2001; Kintsch \& Bowles, 2002; Gibbs \& Matlock, 2008; Coulson, 2008; Coulson \& Lai, 2015; Kiose, 2018). They can be grouped into three oppositions based on the relations of the integrating domains or spaces: 1) dis-analogy vs. analogy; 2) integration process with a semantic shift (metaphoric, metonymic, or metaphtonymic) vs. smooth integration; 3) novel use of the integration model vs. repeated use.

Dis-analogy (resulting in irony and sarcasm) leads in all cases to the figurative noun status. For example, in (3), which shows how the girl Amy is bullied at school and one of her classmates sarcastically addresses her in an offensive way, the only possible interpretation of the dis-analogy model is 'She is not a princess but someone who causes irritation':

(3) [of a girl Amy] "Princess Amy" can't be bothered to bring her script (A. Faber, E. Mazlish). 
Here two mutually exclusive semantic components are brought together, 'having priority status' from the mental space PERSON WITH ROYAL STATUS, and 'being an equal member of the group' from the mental space SCHOOLGIRL, with Princess Amy being an example of sarcasm. The default response is context-dependent and is possibly additionally facilitated by the inverted commas which make the lexeme stylistically and visually more prominent. The noun phrase Princess Amy (in cases where the dis-analogy integration model was recognized by the reader) will be identified as figurative.

In (4) the semantic shift based on analogy is clearly metaphoric:

(4) I don't know why it is, rich men's sons are always the worst lemons (P.G. Wodehouse).

The noun phrase the worst lemons illustrates the integration of the mental spaces MAN and FOOD with the semantic component 'sour' brought from the mental space FOOD. The implication related to the man in the following context is 'difficult to deal with, arousing negative emotions'.

Figurative discourse nouns can get entrenched in discourse through their repeated use, i.e. the reader may no longer interpret them as figurative. Example (5) shows that the process of multiple naming of one and the same referent (women) is applied, by using the same noun vultures:

(5) They started laying bets around Fleet Street as to how long it would be before some nice young woman managed to persuade the little fellow that she must look after him. Naturally, the vultures started gathering at once, they scrambled for the body [...]. Vultures as a bunch of agile crabs under water [...]. (R. Dahl)

In this passage the lexeme vultures is used twice to name the referents (women eager to get married to a rich man). It is obvious that the repetitive use of the same figurative noun (here it is based on analogy and metaphoric shift) transforms the structure of the integrated space: the reader simply gets accustomed to the initially new element of 'carnivorous'. This element is no longer new, which means that the noun vultures may no longer be processed (by the reader) as novel figurative. It becomes a more entrenched one used to identify a group of women.

The three cognitive parameters - namely, the mental spaces integration type (analogy, dis-analogy), the integration character (accompanied by a semantic shift or smooth), the noun's discursive role (novel or entrenched) may be referred to as rigid, which means that in cases where these parameters are recognized, a reader is able to process the default response. 
The rigid parameters display a cognitive nature, they do not have explicit and unambiguous triggers in the discourse and cannot immediately work out a default response based on a consistent algorithm. However, we can rely on some linguistic parameters of the cognitive mechanisms that accelerate default responses, with the mechanism of salience being definitely one of the most reliable. Among these salience parameters there are some of the parameters of focusing that will attract the reader's attention to the potentially ambiguous but relevant piece of information.

Linguistic parameters of focusing (Verhagen, 2007; Iriskhanova, 2014, among others) are language type dependent and have different salience potential in prompting figurative responses in different languages. For example, in Russian, inversion is clearly less focal than in English, as it is much more typical and common in the Russian language due to the language's less fixed syntactic structure. At the same time, the salience potential of inversion in prompting figurativeness may be high in both languages, which can be explored through frequency effects.

In this research we will deal with the syntactic parameters of figurative nouns within Russian sentences. For instance, both initial and final lexeme positions in Russian are considered focal, as well as the (nuclear) position in a mononuclear sentence, but the index of salience may be different for each case, which means that syntactic salience has its own scale of gradation, affecting default responses sequence.

To elicit the syntactic salience parameter values, we will apply corpus analysis using the National Corpus of the Russian Language (NCRL) to check the salience gradation of several non-rigid syntactic parameters of focusing. Then we will proceed to verify their salience in an oculographic experiment. As a result, we plan to find out how the lexical salience of figurative nouns is synchronized with syntactic salience affecting default and non-default interpretations.

\section{Syntactic salience parameters and figurativeness: Corpus analysis of contemporary Russian prose}

The first step was to evaluate the relative frequency of the selected syntactic parameters of focusing in the corpus and form several subcorpora of their use as samples. Then, within the created subcorpora, we manually differentiated between literal and figurative nouns, and between novel and entrenched ones. This procedure was accomplished to see how frequently the chosen syntactic parameters accompany novel figurative nouns, 
The interplay of syntactic and lexical salience and its effect on default...

i.e. may serve as the parameters of syntactic salience for the default responses.

For this study, we used the fiction prose subcorpus of the National Corpus of the Russian Language (NCRL), where the additional requirement of publication period (texts published after 1950) was applied. The total size of the NCRL is 119,203 documents and 288,727,494 words; the size of the contemporary fiction prose subcorpus of NCRL amounts to 3,770 documents and $63,922,856$ words.

In the present paper, we introduce the salience index for a group of focal syntactic parameters. These parameters were selected as the most commonly cited parameters of focusing in various classifications. These include the following:

Parameter 1: the use of the first word in a sentence;

Parameter 2: the use of the first word in a mononuclear sentence;

Parameter 3: the use of the post-attributive position in a mononuclear sentence;

Parameter 4: the use of a sentence-final predicate or subject (inversion) position.

Inside the subcorpus, the tagging applied predetermined specific tags for each parameter search. For instance, for Parameter 1, the syntactic tag was "sentence-initial", lexical tag was "noun". For Parameter 2, the syntactic tag was "sentence-final", lexical tag was "noun". For Parameter 3, the lexical tag was changed into "adjective and noun"; for Parameter 4, the syntactic tag was changed into "sentence-final".

The numeric results of the search are presented in Table 1.

Table 1

Syntactic parameters and their corpus frequency

\begin{tabular}{|l|c|c|c|c|}
\cline { 2 - 5 } \multicolumn{1}{c|}{} & Parameter 1 & Parameter 2 & Parameter 3 & Parameter 4 \\
\hline Number of documents & 3,769 & 3,549 & 3,551 & 3,739 \\
\hline Number of samples & $1,418,776$ & $1,553,759$ & $1,827,346$ & $1,995,862$ \\
\hline
\end{tabular}

Due to the large size of the subcorpora collected, we had to apply the additional procedure of random samples selection for further demarcation of literal and figurative nouns. The corpus analysis procedure to differentiate them is generally based on the MIPT VU method of cognitive metaphor identification (e.g. Steen et al., 2010), although we had to introduce additional criteria for demarcating conventional (entrenched) and novel (nonentrenched) figurativeness. The partly automatic, partly manual corpus search procedure we apply has been adopted in similar studies, although 
with a different aim and on different data (Semino \& Short, 2004; Gries \& Stefanowitsch, 2006; Golubkova, 2014; Diviak, 2015), where preliminary results extracted from a corpus underwent further manual processing, thus the implemented research method was both corpus-driven and corpus-based (Tognini-Bonelli, 2001).

The corpus-driven procedure for the demarcation of literal and figurative nouns is very time-consuming and labour-intensive, as the further selection is done manually (there is no chance of launching a search based on this or that lexeme frequency as we deal with figurative non-entrenched nouns only) and there are no rigid linguistic indicators that would mark the noun status. In differentiating literal and figurative novel discourse nouns we were guided by the following procedure:

1) determination of at least one of the rigid parameters of figurativeness of the noun lexeme or noun phrase under examination (dis-analogy as domain-integration type, semantic shift as domain-integration character, and novel or entrenched noun use);

2) inspection of the lexeme's meaning in the dictionary to see if the figurative meaning activated in the discourse had already been introduced into the mental lexicon (in case any of the rigid parameters were detected);

3) validation of the non-entrenched character of the lexeme (also in word combination) by means of checking its frequency in the corpus for the meaning activated (in case its meaning was not recorded in the dictionary);

4) extraction of the focal linguistic parameters of the noun (in the present study these will include only several syntactic parameters);

5) statistical processing of the focal linguistic parameters to check their concordance with rigid parameters of the noun status.

The search results were further processed manually, following the procedure steps described above, to differentiate the literal and figurative uses of nouns. For Parameters 2, 3, and 4, we had to additionally manually extract only mononuclear sentences or sentences where the noun was used as a subject or predicate, as this could not be accomplished through corpus tagging.

We will demonstrate the research procedure carried out with Parameter 2, that is, "the use of the first word in the mononuclear sentence", which was also used to identify the salience indices of other parameters.

With the tags applied ("sentence-initial" and "noun"), the preliminary search revealed 3,549 text fragments including 1,553,759 lexical units. We selected for further analysis only the first usage pattern on a search page, 
The interplay of syntactic and lexical salience and its effect on default...

ascertaining that these patterns belonged to various authors. Thus, we considerably reduced the amount of manual processing, and removed the effect of author individuality in salience marking. Only mononuclear sentences were hand-selected from the total number of the use patterns. With this procedure completed, we collected 313 sentence-initial nominal units with suspended status (literal or figurative).

The following 5 -step status differentiation procedure revealed that 85 of the nominal units (out of 313 ) were figurative, constituting $27 \%$ of all the cases of nouns as the first word in mononuclear sentences. The high frequency index of this focal syntactic position may indicate its high salience for the processing of figurative discourse nouns, which we will later verify experimentally. Some of the typical examples and comments on their use are given below $(6-8)$.

(6) Деньги должны не лежать, а вкладываться. Закаты, рассвеmbl, здоровье. [Money has to be invested. Sunsets, dawns, health] (NCRL).

(7) И не хами! Пигалица еще! [Stop being rude! You are nothing!] (NCRL).

(8) В пакете было приглашение правительства. Приглашение в плен. [The package contained an invitation. Imprisonment invitation] (NCRL).

For instance, it is worth mentioning that 69 figurative nouns out of the 85 extracted had a literal counterpart in pre-position. In (6), the literal counterpart for the figurative chain of the nouns закать, рассветьл, здоровье is деньги ('money'), which is used in the previous sentence as a subject. More than a half of the 228 literal nouns are entrenched figurative nouns. For example, in (7), the lexeme пигалича, literally meaning 'a small bird', refers to a female; in the dictionary its figurative meaning is given as the primary meaning, whereas its literal meaning has become very rare. All the 110 use patterns extracted from the National Corpus of the Russian Language demonstrate the figurative status of the noun, which proves its entrenched character. Among the 85 figurative non-entrenched lexemes there were 26 morphological deverbatives. In (8), the lexeme приглашение derives from the verb приглашать ('to invite'). We consider that a large number of figurative nominal deverbatives may signify that they are very typical of discourse figurativeness construal.

The same procedure was applied to define the frequency indices of $\mathrm{Pa}$ rameters 1 to 4 , which are presented in Table 2 . 
Table 2

Syntactic parameters and the indices of their figurative noun use frequency

\begin{tabular}{|l|c|}
\multicolumn{1}{|c|}{ Parameter } & $\begin{array}{c}\text { Frequency } \\
\text { index }\end{array}$ \\
\hline Parameter 1: the use of the first word in a sentence & 0.08 \\
\hline Parameter 2: the use of the first word in a mononuclear sentence & 0.27 \\
\hline Parameter 3: the use of the post-attributive position in a mononuclear sentence & 0.33 \\
\hline Parameter 4: the use of the sentence-final position & 0.2 \\
\hline
\end{tabular}

The results show that while the use of figurative non-entrenched nouns in mononuclear sentences, post-attributive position included, and in sentence-final predicate position is very frequent, its use as the first word in the sentence or the sentence-final subject position tends to be comparatively rare. This may mean that Parameter 3 demonstrates the highest salience for default response processing, then comes Parameter 2, followed by Parameter 4 and Parameter 1, the last one with the lowest salience. The low frequency index of Parameter 1 may be explained by the fact that the sentence-initial position in written texts in Russian is mostly syntactically thematic, whereas for texts in oral form, the syntactical salience of this position is much higher due to the frequent use of emphatic structures. The low frequency index of Parameter 4, though unexpected, may result from the conventional character of inversion in the Russian language (as has been mentioned above), which results in its lower salience in inflexional languages like Russian (it may mark both literal and figurative nouns), as opposed to languages with fixed syntactic structure.

In the oculographic experiment we will verify the degrees of salience of these parameters and try to discover how different degrees of salience affect a reader's interpretation routes.

\section{Graded syntactic and lexical salience: oculographic verification}

\subsection{Aim}

We aimed to test the syntactic salience influence on default figurative responses. To that end, we conducted an eye-tracking experiment where we checked the participants' default and non-default responses, as well as oculographic data ascertaining the increase and decrease in cognitive load (increased fixation duration). To prepare the stimulus texts with figurative 
nouns, we considered various oculographic requirements in terms of eyetracking experiment management and text formatting (Rayner \& Pollatsek, 1989; Rayner, 1998; Kliegl et al., 2006; Staub, 2015; Faucett et al., 2015, among others). Many of these studies, for instance, used even inter-lexeme intervals and pre- and post-reading line intervals, as well as wide intervals between the lines to facilitate the deciphering procedure and alleviate their influence on the reading process. We also checked that none of the figurative lexemes was of an entrenched character; the corpus frequency of the lexemes, as well as the number of meanings, were previously defined to provide possible explanations for inconsistent experiment results (the factors of frequency and prototypicality in R. Giora's classification of lexical salience parameters). To test the graded character of syntactic salience, the first three parameters were chosen, with Parameters 1 and 2 demonstrating significant differences in salience and Parameters 2 and 3 demonstrating the same high salience during the corpus analysis. The lexical salience factors (like the lexeme corpus frequency and the prototypicality) were also considered to see how the syntactic and lexical parameters will be synchronized.

\subsection{Participants and task}

The participants in the experiment were 12 native speakers of Russian, aged 19-22, students, who were asked to read the text and prepare to answer some of the questions about the text asked by the interlocutor after the participant had finished reading. The questions proposed concerned the reference interpretation of the figurative nouns and noun phrases. They were offered in the following format about each of the figurative nouns used: What does псина 'bitch' mean? What does псина 'bitch' refer to in the text?

Кот Василий медленно подошел к окну. Фсина! - вдруг заорал визгливый
голос хозяйки. Сказка, а не жизнь»- подумал кот и на всякий случай спрятался
за цветочный горшок, «Ну подумаешь, выкрал сардельку. Тоже мне. Мясной
деликатее. Тухлая радость Теперь вот прячься» Бочка гневя вкатилась в дверь.
Бочка гнсва трещала от злобы. Бочка гнева приблизилась к цвсточному горшку.
«Цветовая гармония - рыжий кот за рыжим горшком», - успел подумать кот.
«Медвежатнивбольше не будет жить в этом доме», - резко взвизгнула хозяйка,
выуживая похитителя тухлой радости из-за горшка. «Барбаросса!Не успею...
Успел!»- с этой мыслью Васька выскользнул из цепких колец бочки.

Figure 1. Stimulus text with figurative nouns and noun phrases (circled) 


\section{Maria Kiose}

The text was of a narrative type; the word-by-word English language annotation and translation is given below.

\section{Line 1}

Кот Василий медленно подошел к окну. «Псина!»-вдруг заорал визгливый [He-cat] [Vasily] [slowly] [came] [to] [window] [glutton] [suddenly] [shouted] [shriek]

Male Cat Vasily slowly came to the window. "Bitch!" - there came out a sudden shriek

\section{Line 2}

голос хозяйки. «Сказка, а не жизнь», - подумал кот и на всякий случай спрятался [voice] [missis] [fairy tale] [but] [not] [life] [thought] [he-cat] [and] [on] [any] [case] [hid] voice of Missis. "Life is a fairy tale" - the Cat thought and hid just in case

\section{Line 3}

за цветочный горшок, «Ну, подумаешь, выкрал сардельку. Тоже мне. Мясной [behind] [flower] [pot] [well] [you will think] [sneaked out] [sausage] [well] [me] [meat]

behind a flower pot, "I guess it's because I sneaked out a sausage. What the hell! A meat

\section{Line 4}

деликатес. Тухлая радость. Теперь вот прячься. Бочка гнева вкатилась в дверь. [delicacy] [rotten] [happiness] [now] [well] [hide] [barrel] [anger] [rolled] [into] [door] delicacy. Rotten happiness. But now I have to hide my head". The barrel of anger broke into the door.

\section{Line 5}

Бочка гнева трещала от злобы. Бочка гнева приблизилась к цветочному горшку. [barrel] [anger] [cracked] [with] [rage] [barrel] [anger] [approached] [to] [flower] [pot]

The barrel of anger was cracking with rage. The barrel of anger approached the flowerpot.

\section{Line 6}

«Цветовая гармония - рыжий кот за рыжим горшком», - успел подумать кот. [colour] [harmony] [red] [he-cat] [behind] [red] [pot] [had time] [to think] [he-cat]

"A harmony of colours - a red cat behind a red flowerpot", the Cat thought.

\section{Line 7}

«Медвежатник больше не будет жить в этом доме», резко взвизгнула хозяйка, [robber] [more] [no] [will] [live] [in] [this] [house] [suddenly] [screamed] [missis]

"The robber won't live under this roof", Missis let out a screech,

\section{Line 8}

выуживая похитителя тухлой радости из-за горшка. «Барбаросса! Не успею... [fishing out] [thief] [rotten] [happiness] [from behind] [pot] [Barbarossa] [don't] [have time] when fishing out the thief of the rotten happiness from behind the pot. "Assault! No time...

\section{Line 9}

Успел!»- с этой мыслью Васька выскользнул из цепких колец бочки. [made it] [with] [this] [thought] [Vaska] [slipped out] [from] [clingy] [rings] [barrel]

I've made it!" - feeling happy, Vasily slipped out of the barrel's rings. 
In Line 1 there is the metaphoric model of transfer SHE-DOG IS HE-CAT in Псина as Bitch. It is used to refer to a he-cat with no identical reference type where this lexeme (псина) was used to refer to a cat in NCRL (in Russian the lexeme псина is feminine, an offensive word for a dog), its frequency index (FI) is equal to 355. Salience Parameter 2 is tested.

In Line 2, the dis-analogy model of POSITIVE IS NEGATIVE transfer was used in Сказка, а не жизнь 'life is a fairy tale' for Тяжела моя жизнь 'life is a difficult thing' with no identical dis-analogy reference type for сказка 'fairy tale', referring to difficult life found in NCRL. The FI of сказка equals 17,574. Salience Parameter 2 is tested.

In Line 4 , the dis-analogy model of EXTRAORDINARY IS USUAL was applied in деликатес 'delicacy' instead of сарделька 'sausage', with 7 out of 100 first NCRL uses of identical dis-analogy type. Here the lexeme деликатес 'delicacy' was used ironically, to stand for ordinary foods, but never in a word combination мясной деликатес 'meat delicacy'. The FI of деликатес equals 631. Salience Parameter 3 is tested.

In Line 4 , the dis-analogy model of POSITIVE IS NEGATIVE transfer, in Тухлая радость 'rotten happiness' meaning Не особо вкусная 'nothing special' was applied. Here two components of a noun phrase are semantically contrastive, presenting extremes on the positive-negative scale; no examples of similar reference use were found in NCRL. The FI of padocmb equals 46,690. Salience Parameter 3 is tested.

In Line 4, the metaphoric model of OBJECT IS PERSON was applied in Бочка гнева 'the barrel of anger' instead of Хозяйка 'Missis', where nо similar reference uses were found in NCRL. The FI of бочкa equals 7,746. Salience Parameter 1 is tested.

In Line 7 , the metaphoric model PERSON IS ANIMAL was used in Медвежатник 'robber' instead of Этот кот 'this cat', with no similar reference of the lexeme медвежатник in NCRL to denote the animal. The FI of the lexeme is 172 . Salience Parameter 1 is tested.

In Line 8, the metonymic model WHOLE FOR PART was applied, with the military operation Барбаросса 'Barbarossa', famous for its tragic consequences within the Russian culture, denoting here the aggressive character of the woman's behavior. In NCRL, there are no metaphoric or metonymic uses of the lexeme, but its two meanings are exploited (with one being a personal name). The FI equals 72. Salience Parameter 2 is tested.

\subsection{Experimental Methodology}

The EYETRIBE eye-tracker running at $30 \mathrm{~Hz}$ and a specially designed program, EyeTrackProc (to process the raw data, present the ScanPath, and 


\section{Maria Kiose}

automatically calculate the number and duration of fixations and saccades), were used for the experiment. For this study we assessed the fixations duration at the areas of interest and the default figurative response index in correlation with the hypothetical degree of salience of the applied syntactic parameters.

We expected that, in cases where a reader deals with figurative nouns whose syntactic positions were significantly more salient (with this assumption rooted in the results of the corpus analysis), the index of default figurative responses, i.e. Default Responses Index (DRI) would be higher, whereas the Average Fixations Duration (AFD) would be shorter. To demonstrate the results, we focus on two parameters differing in salience: Parameter 1 (the use of the first word in a sentence, NCRL frequency 0.08) and Parameter 2 (the use of the first word in a mononuclear sentence, NCRL frequency 0.27 ). These parameters were exemplified in two noun phrases for each parameter: $\mathrm{NP}_{1}$ Псина and $\mathrm{NP}_{4}$ Барбаросса for Parameter 2, and $\mathrm{NP}_{2}$ Медвежатник and $\mathrm{NP}_{3}$ Бочка for Parameter 1.

\subsection{Results}

The results of the experiment are given in Table 3 below, in which each of the 12 participants' Fixations Duration (in seconds, the sum of all the fixations duration in the area) for the areas of interest are presented.

In Table 4 below, the Average Fixations Duration (AFD), Default Responses Index (DRI) and Average Fixations Duration in the case of Default Response (AFD DR) are given.

If we compare DRI and AFD of two lexemes $\mathrm{NP}_{1}$ Псин $a$ and $\mathrm{NP}_{2}$ Медвежатник with similar corpus frequency but in varying syntactic positions (with higher and lower salience), we see the expected differences in DRI and AFD with higher default figurative responses and shorter reading times in salient positions. But there was an unexpected distinction in the AFD in cases of correct and wrong reference interpretation in the contrasting lexemes. We noticed that in the case of correct reference interpretation, i.e., in cases of default responses, the Average Fixation Duration (AFD DR) in the lower salience syntactic position of Медвежатник was much longer. This cannot be explained by the fact that the coreference distance is longer, as in the case of Медвежатник it is 0, whereas in Псина it is 6 words. There is also no change in the lexeme agentivity, case, or stylistic marking in both cases. We think that this might happen because of the differences in the prototypicality of meaning. Here ППина is exploited in the prototypical 
The interplay of syntactic and lexical salience and its effect on default...

Table 3

Noun phrases reading times (Fixations Duration)

\begin{tabular}{|c|c|c|c|c|}
\hline & $\begin{array}{c}\mathbf{F D} \mathbf{N P}_{1} \\
\text { Псина }\end{array}$ & $\begin{array}{c}\mathbf{F D} \mathbf{N P}_{2} \\
\text { Медвежатник }\end{array}$ & $\begin{array}{c}\mathbf{F D} \mathbf{N P}_{3} \\
\text { Бочка }\end{array}$ & $\underset{\text { Барбаросса }}{\mathbf{F D ~} \mathbf{N P}_{4}}$ \\
\hline Participant 1 & 0.99 & 0.60 & 0.84 & 0.36 \\
\hline Participant 2 & 0.45 & 0.84 & 0.00 & 0.00 \\
\hline Participant 3 & 1.02 & 1.44 & 0.57 & 0.39 \\
\hline Participant 4 & 0.60 & 0.39 & 0.48 & 0.90 \\
\hline Participant 5 & 0.45 & 1.17 & 0.69 & 0.30 \\
\hline Participant 6 & 0.42 & 0.72 & 1.05 & 0.63 \\
\hline Participant 7 & 0.54 & 0.90 & 0.93 & 0.87 \\
\hline Participant 8 & 0.81 & 0.00 & 1.08 & 1.95 \\
\hline Participant 9 & 0.78 & 0.90 & 0.57 & 0.00 \\
\hline Participant 10 & 0.24 & 0.75 & 0.00 & 0.87 \\
\hline Participant 11 & 0.75 & 0.87 & 0.75 & 0.87 \\
\hline Participant 12 & 0.57 & 1.02 & 0.78 & 1.47 \\
\hline
\end{tabular}

Table 4

Noun phrases oculographic and Default Response values

\begin{tabular}{|l|c|c|c|c|}
\cline { 2 - 5 } \multicolumn{1}{c|}{} & $\mathbf{N P}_{1}$, Parameter 2 & $\mathbf{N P}_{2}$, Parameter 1 & $\mathbf{N P}_{3}$, Parameter 1 & $\mathbf{N P}_{4}$, Parameter 2 \\
\hline AFD & 0.635 & 0.873 & 0.610 & 0.861 \\
\hline DRI & 0.83 & 0.66 & 0.66 & 0.33 \\
\hline AFD DR & 0.678 & 1.000 & 0.731 & 1.08 \\
\hline
\end{tabular}

obscene meaning but refers to a cat, not a dog, whereas Медвежатник in its prototypical meaning, denoting thieves who break into houses by unlocking the door professionally, realizes a more complex metaphoric transfer model.

If we compare the Default Responses Indices and Fixations Duration of the figurative lexemes with different corpus frequencies and degrees of meaning prototypicality, we will clearly see that these factors were decisive. Thus, DRI of the lexeme Псина with a high corpus frequency is almost three times higher than that of the lexeme Барбаросса with low corpus frequency. Average Fixations Duration, though, is not so demonstrative, but the Average Fixations Duration in situations of default responses was significant. 


\section{Maria Kiose}

In cases where the reader correctly identified the figurative character of lexemes with a low corpus frequency, the fixation duration was considerably longer. The low DRI and longer AFD DR in Барбаросса may be explained by the fact that this lexeme has several distinct meanings in the mental lexicon of the young people, one being the military operation mentioned above, and the others for the emperor F. Barbarossa and for the pirate Barbarossa (both the real and the blockbuster characters). This ambiguity may have caused the readers' reaction time to increase.

At the same time, the DRI, AFD and AFD DR of the lexemes Псина (Parameter 2) and Бочка (гнева) (Parameter 1) do not demonstrate any significant difference, but this might be the result of their varied corpus frequency with the much higher index in Бочка.

Thus, the results have shown that syntactic salience does not directly influence the default responses to the novel figurative nouns. Instead, it is synchronized with lexical salience. Somewhat unexpectedly, it is not directly associated with shorter fixation duration, with the latter correlating with less successful reference identification. All in all, other factors of salience may turn out to play a more decisive role in the interpretation of figurative nouns, such as the lexeme's frequency in the corpus and meaning prototypicality, as well as their intricate combinations.

\section{Conclusion}

The research was aimed at verifying the influence of syntactic salience factors on the processing of figurative discourse nouns and noun phrases. The results show that the Graded Salience and Defaultness hypotheses worked out by R. Giora (2003; Giora et al., 2015) do explain why some figurative nouns are processed better, even when exploring the interplay of various salience parameters, here lexical and syntactic ones. Syntactic salience as well as lexical salience both contribute to eliciting default responses, although the synchronization schemes of lexical and syntactic salience parameters are very complicated.

To assess the role of syntactic salience in the elicitation of the default meaning of non-entrenched (novel, unconventional) figurative nouns, we addressed several syntactic parameters of focusing (the use of the first word in a sentence, the first word in a mononuclear sentence, the post-attributive position in a mononuclear sentence, the sentence-final position) which might serve to attract the reader's attention to noun phrases. Applying the procedure of complex corpus analysis (semi-automatic and semi-manual, due to 
the necessity to study only non-entrenched figurative nouns) we identified the frequency index of these parameters, which represents their frequency of being used together with non-entrenched figurative nouns. Assuming that a higher frequency index may co-occur with higher salience effects, we proceeded to experimental verification of the hypothesis.

With a group of syntactic parameters demonstrating different hypothetical salience, we identified how the salience gradation influences default responses in processing figurative non-entrenched nouns. In the eye-tracking experiment we considered both the eye-movement characteristics of participants and their default responses index, i.e. correct reference identification. Although we noticed some expected correlations of the syntactically salient use of figurative nouns and their default interpretation, the overall reading and interpretation dependencies were not so evident. In some cases, the lexical salience factor was more decisive. We also found the dependencies of reading time and correct reference identification. All in all, it has become obvious that the relations between lexical and syntactic parameters of salience are far from being simply complementary, with better interpretation performance depending on a variety of ad hoc resonant salience parameters.

\section{Funding}

This research is financially supported by the Russian Foundation for Basic Research, project No. 20-012-00370 "Textual heterogeneity and the factors of its successful reading comprehension" at Moscow State Linguistic University.

\section{R E F E R E N C E S}

Barsalou, L. W. (2008). Grounded cognition. Annual Review of Psychology, 59, 617-645.

Bergen, B. K. (2012). Louder than words: The new science of how the mind makes meaning. New York: Basic Books.

Chafe, W. (1994). Discourse, consciousness and time: The flow and displacement of conscious experience in speaking and writing. Chicago: Chicago University Press.

Charteris-Black, J. (2012). Shattering the bell jar: Metaphor, gender and depression. Metaphor and symbol, 27(3), 199-216.

Coulson, S. (2008). Metaphor comprehension and the brain. In R. W. Gibbs (Ed.), The Cambridge handbook of metaphor and thought (pp. 177-194). New York: Cambridge University Press.

Coulson, S., \& van Petten, C. (2002). Conceptual integration and metaphor: an event-related potential study. Memory and Cognition, 30(6), 958-968. 


\section{Maria Kiose}

Coulson, S., \& Lai, V. T. (2015). The metaphorical brain. Lausanne: Frontiers Media.

Divjak, D. (2015). Exploring the grammar of perception. A case study using data from Russian. Functions of Language, 22(1), 44-68.

Faucett, J. M., Risco, E. F., \& Kingstone, A. (2015). The handbook of attention. Cambridge, MA: MIT Press.

Gentner, D., Bowdle, B. F., Wolff, P., \& Boronat, C. (2001). Metaphor is like analogy. In D. Gentner, K. J. Holyoak \& B. N. Kokinov (Eds.), The analogical mind: Perspectives from cognitive science (pp. 199-253). Cambridge, MA: MIT Press.

Gibbs, R. W. (1992). Categorization and metaphor understanding. Psychological Review, 99, 572-577.

Gibbs, R. W., \& Matlock, T. (2008). Metaphor, imagination, and simulation: Psycholinguistic evidence. In R. W. Gibbs (Ed.), The Cambridge handbook of metaphor and thought (pp. 161-176). New York: Cambridge University Press.

Giora, R. (1999). On the priority of salient meanings: Studies of literal and figurative language. Journal of Pragmatics, 31(7), 919-929.

Giora, R. (2003). On our mind: Salience, context, and figurative language. Oxford: Oxford University Press.

Giora, R., \& Fein, O. (1999). Irony: Context and salience. Metaphor and Symbol, $14(4), 241-257$.

Giora, R., Givoni, S., \& Fein, O. (2015). Defaultness reigns: The case of sarcasm. Metaphor and Symbol, 30(4), 290-313.

Giora, R., Jaffe, I., Becker, I., \& Fein, O. (2018). Strongly mitigating a highly positive concept: The case of default sarcastic interpretations. Review of Cognitive Linguistics, 6(1), 19-47.

Givón, T. (1987). Beyond foreground and background. In R. S. Tomlin (Ed.), Coherence and grounding in discourse (pp. 175-168). Amsterdam and Philadelphia: John Benjamins Publishing Company.

Glucksberg, S., Gildea, P., \& Bookin, H. B. (1982). On understanding non-literal speech: Can people ignore metaphors? Journal of Verbal Learning and Verbal Behavior, 1, 85-96.

Glucksberg, S., \& Keysar, B. (1990). Understanding metaphorical comparisons: Beyond similarity. Psychological Review, 97(1), 3-18.

Gold, R., \& Faust, M. (2010). Right hemisphere dysfunction and metaphor comprehension in young adults with Asperger syndrome. Journal of Autism and Developmental Disorders, 40(7), 800-811.

Golubkova, E. E. (2014). Ispolzovaniye lingvisticheskih korpusov pri reshenii semanticheskikh problem. In V. I. Zabotkina \& E. E. Golubkova (Eds.), Metody kognitivnogo analiza semantiki slova: Komputerno-korpusnyi podkhod (pp. 34-75). Moscow: Yazyki Slavianskoi Kultury. (In Russ.). 
Gries, S. T., \& Stefanowitsch, A. (Eds.) (2006). Corpora in cognitive linguistics: Corpus-based approaches to syntax and lexis. Berlin and New York: Mouton de Gruyter.

Hetmański, M. (2015). Metaphoric confinement of information. Studies in Logic, Grammar, and Rhetoric,40(53), 161-178.

Iakimova, G., Passerioux, C., Denhière, G., Laurent, J.-P., Vistoli, D., Vilain, J., \& Hardy-Baylé, M.-C. (2010). The influence of idiomatic salience during the comprehension of ambiguous idioms by patients with schizophrenia. Psychiatry Research, 177(1-2), 46-54.

Iriskhanova, O. (2014). Igry fokusa v yazyke: Semantika, sintaksis i pragmatika defokusirovaniya. Moscow: Yazyki Slavianskoi Kultury. (In Russ.).

Kauschke, C., Mueller, N., Kircher, T., \& Nagels, A. (2018). Do patients with depression prefer literal or metaphorical expressions for internal states? Evidence from sentence completion and elicited production. Frontiers in Psychology, 9, Article 1326.

Kazmerski, V. A., Blasko, D. G., \& Dessalegn, B. G. (2003). ERP and behavioral evidence of individual differences in metaphor comprehension. Memory and Cognition, 31(5), 673-689.

Kiose, M. (2018). Factors of co-referent indirect names interpretation in text: Cognitive analysis - statistics - experiment. Issues in Cognitive Linguistics (Voprosy kognitivnoy lingvistiki), 3, 16-26. (In Russ.).

Kintsch, W., \& Bowles, A. (2002). Metaphor comprehension: What makes a metaphor difficult to understand? Metaphor and Symbol, 17(4), 249-262.

Kliegl, R., Nuthmann, A., \& Engbert, R. (2006). Tracking the mind during reading. The influence of past, present, and future words on fixation duration. Journal of Experimental Psychology: General, 135, 12-35.

MacKay, G., \& Shaw, A. (2004). A comparative study of figurative language in children with autistic spectrum disorders. Child Language Teaching and Therapy, 20, 13-32.

National corpus of the Russian language. Retrieved from http://www.ruscorpora.ru/

Norbury, C. F. (2005). The relationship between theory of mind and metaphor: Evidence from children with language impairment and autistic spectrum disorder. Developmental Psychology, 23(3), 383-399.

Pynte, J., Besson, M., Robichon, F.-H., \& Poli, J. (1996). The time-course of metaphor comprehension: an event-related potential study. Brain and Language, 316, 293-316.

Rapp, A. M., Felsenheimer, A. K., Langohr, K., \& Klupp, M. (2017). The comprehension of familiar and novel metaphoric meanings in schizophrenia: A pilot study. Frontiers in Psychology, 8, Article 2251.

Rayner, K. (1998). Eye movements in reading and information processing: 20 years of research. Psychological Bulletin, 124(3), 372-422. 
Rayner, K., \& Pollatsek, A. (1989). The psychology of reading. Englewood Cliffs, NJ: Prentice Hall.

Ritchie, D. (2013). Metaphor. Cambridge: Cambridge University Press.

Rundblad, G., \& Annaz, D. (2010). The atypical development of metaphor and metonymy comprehension in children with autism. Autism, 14, 29-46.

Semino, E., \& Short, M. (2004). Corpus stylistics: Speech, writing and thought presentation in a corpus of English writing. London: Routledge.

Schmid, H.-J. (2007). Entrenchment, salience, and basic levels. In D. Geeraerts \& H. Cuyckens (Eds.), The Oxford handbook of cognitive linguistics (pp. 117138). Oxford: Oxford University Press.

Staub, A. (2015). Reading sentences: Syntactic parsing and semantic interpretation. In A. Pollatsek \& R. Treiman (Eds.), The Oxford handbook of reading (pp. 202-216). Oxford: Oxford University Press.

Steen, G., Dorst, A. G., Herrmann, J. B., Kaal, A. A., Krennmayr, T., \& Pasma, T. (2010). A method for linguistic metaphor identification: From MIP to MIPVU. Amsterdam: John Benjamins.

Talmy, L. (2000). Toward a cognitive semantics. Vol. 1. Concept structuring systems. Cambridge, MA and London: MIT Press.

Tomlin, R. S. (1987). Linguistic reflections of cognitive events. In R. S. Tomlin (Ed.), Coherence and grounding in discourse (pp. 455-479). Amsterdam and Philadelphia: John Benjamins.

Tognini-Bonelli, E. (2001). Corpus linguistics at work. Amsterdam: John Benjamins.

Tversky, A., \& Kahneman, D. (1974). Judgment under uncertainty: Heuristics and biases. In A. Tversky \& D. Kahneman (Eds.), Judgment under uncertainty: Heuristics and biases (pp. 3-28). Cambridge: Cambridge University Press.

Verhagen, A. (2007). Construal and perspectivization. In D. Geeraerts \& H. Cuyckens (Eds.), The Oxford handbook of cognitive linguistics (pp. 48-81). Oxford: Oxford University Press.

Vulchanova, M., Saldańa, D., Chahboun, S., \& Vulchanov, V. (2015). Figurative language processing in atypical populations: the ASD perspective. Frontiers in Human Neuroscience, 9, Article 24.

Wårwik, B. (2004). What is foregrounded in narratives? Hypotheses for the cognitive basis of foregrounding. In T. Virtanen (Ed.), Approaches to cognition through text and discourse (pp. 99-122). Berlin and New York: Mouton de Gruyter. 